\title{
Erratum to: Cell Wall Composition and Ruminant Digestibility of Various Maize Tissues Across Development
}

\author{
Candice N. Hansey • Aaron J. Lorenz • Natalia de Leon
}

Published online: 29 July 2010

(C) Springer Science+Business Media, LLC. 2010

Erratum to: Bioenerg. Res. (2010) 3:28-37

DOI 10.1007/s12155-009-9068-4

\begin{abstract}
Maize stover, including stalks, leaves, and cobs, has potential utility as a cellulosic biofeedstock. Understanding how total stover ethanol potential is affected by the proportion and quality of major plant components would facilitate the genetic improvement of stover quality and inform decisions regarding which plant parts should be targeted for harvesting. Our objectives were to determine how the proportion and composition of plant components affected ethanol potential and whether there are early season predictors of stover quality at maturity. Twentythree hybrids were evaluated including 20 from a factorial mating design between five silage inbred lines and four commercial inbreds and a brown-midrib3, a Leafyl, and a commercial grain hybrid checks. Plants were harvested and dissected into component parts at developmental stages vegetative 3 , vegetative 12 , reproductive 3 , and reproductive 6 (R6). Tissues were evaluated for acid detergent fiber (ADF), neutral detergent fiber (NDF), and NDF digestibility (NDFD). Stalk was the largest fraction of whole plant dry matter $(46.2 \%)$ and had the lowest NDFD $(375.0 \mathrm{~g} / \mathrm{kg}$ ) at R6. No relationship was found between stalk ADF at early developmental stages and whole plant
\end{abstract}

The online version of the original article can be found at http://dx.doi. org/10.1007/s12155-009-9068-4. This paper, originally published in BioEnergy Research, Volume 3, Number 1, March 2010, contained errors on the units of measurement. The corrected version of this paper is reprinted here in its entirety.

C. N. Hansey · A. J. Lorenz • N. de Leon $(\bowtie)$

Department of Agronomy, University of Wisconsin-Madison,

1575 Linden Drive, Madison, WI 53706, USA

e-mail: ndeleongatti@wisc.edu
ADF at R6, suggesting that quality at early developmental stages is not indicative of quality at physiological maturity. Differences were observed among hybrids for ADF and NDF for most plant parts evaluated. Hybrid-bydevelopmental stage and hybrid-by-plant part interactions were statistically significant. This indicates that there is minimal opportunity to identify superior hybrids for biofuel production based on the proportion of total biomass represented by a plant part and its quality at early developmental stages. Maximum conversion efficiency is attained when leaves are harvested compared to other tissue types at physiological maturity.

Keywords Biofeedstock · Cell wall · Digestibility · Maize · Selection

$\begin{array}{ll}\text { Abbreviations } \\ \text { USDA } & \text { US Department of Agriculture } \\ \text { V3 } & \text { Vegetative } 3 \\ \text { V12 } & \text { Vegetative 12 } \\ \text { R3 } & \text { Reproductive } 3 \\ \text { R6 } & \text { Reproductive } 6 \\ \text { WQS } & \text { Wisconsin Quality Synthetic } \\ \text { bm3 } & \text { brown-midrib3 } \\ \text { Lfy1 } & \text { Leafy1 } \\ \text { SSF } & \text { Simultaneous saccharification and fermentation } \\ \text { NDF } & \text { Neutral detergent fiber } \\ \text { ADF } & \text { Acid detergent fiber } \\ \text { ADL } & \text { Acid detergent lignin } \\ \text { IVTD } & \text { In vitro true digestibility } \\ \text { NDFD } & \text { Neutral detergent fiber digestibility } \\ \text { IVR } & \text { In vitro ruminal fermentation }\end{array}$




\section{Introduction}

The US Department of Agriculture (USDA) and the Department of Energy have jointly predicted that approximately one billion dry tons of biomass will be needed annually to replace $30 \%$ of the 2004 's consumed transportation fuel with biofuels by 2030 . In the USA, it has been estimated that approximately $20 \%$ of the billion dry tons of biomass will come from maize stover, which refers to the aboveground plant matter excluding the grain. Maize stover represents approximately $75 \%$ of the 194 million dry tons of the biomass currently available in the USA [32].

There are two aspects of biomass composition that are important in determining ethanol yield potential from biofeedstock based on the simultaneous saccharification and fermentation (SSF) current conversion methods, the structural carbohydrate concentration, and the convertibility of the structural carbohydrates. The structural carbohydrate concentration is a measure of the complex carbohydrates, such as cellulose and hemicellulose, in the cell wall. The convertibility is a measure of the cell wall digestibility or the accessibility of available total cell wall carbohydrates by the fermenting organisms. The convertibility is determined in part by the concentration and composition of different lignin types present in the cell wall [39].

Currently, the biochemical conversion of cellulosic biomass to ethanol is a three-step process: physical size reduction and thermochemical pretreatment, enzymatic hydrolysis of the cell wall polysaccharides, and fermentation of the simple sugars. The last two steps in the process can be combined into a process known as $\operatorname{SSF}[11,12,25]$. Evaluation of stover quality by SSF is not practical on a large scale due to the time-consuming nature of the procedure. Alternative protocols have been developed that are less time intensive [19]. These methods, however, are still not ideal for high-throughput settings such as largescale plant breeding program.

An alternative to the SSF approach is to determine structural carbohydrate and lignin concentration and use this information to predict ethanol yield. The detergent-based methods are a well-established method to measure composition concentrations. Forage quality laboratories and research groups routinely use these methods $[1,3,5,6,8,16,22]$. Development of near-infrared spectroscopy (NIRS) calibrations based on the detergent-based methods can be used to predict these components in a high-throughput manner.

The detergent methods include neutral detergent fiber (NDF), acid detergent fiber (ADF), and acid detergent lignin (ADL) [40]. These methods estimate fractions of the cell wall by insolubility in various solutions. NDF estimates total cell wall fiber by insolubility in neutral detergent. ADF estimates the cellulose and lignin fraction by insolubility in acid detergent. ADL estimates the acid insoluble lignin fraction by insolubility in $72 \%$ sulfuric acid. Cellulose and hemicelluloses can be determined from these fractions as NDF minus $\mathrm{ADF}$ and $\mathrm{ADF}$ minus $\mathrm{ADL}$, respectively. NDF, cellulose, and hemicelluloses concentrations are measures of the structural carbohydrate concentration. Another forage quality method, in vitro true digestibility (IVTD), measures the percent dry matter disappearance after a 48 -h incubation in rumen fluid [37]. The neutral detergent fiber digestibility (NDFD) can be determined by combining the NDF with IVTD to provide a measure of carbohydrate concentration and convertibility [38, 40]. A similar assay measuring gas production obtained from in vitro ruminal fermentation was shown to be correlated with SSF ethanol yields [42]. Canonical correlations that include the structural carbohydrate concentration and convertibility estimates based on these forage quality methods provide appropriate predictions of ethanol potential based on the performance of pretreated samples converted to ethanol by SSF. Specifically, NDFD, a measure of the concentration and convertibility of the cellulose fraction of fiber, is highly predictive of ethanol yield from cellulosic biomass [26].

The yield of ethanol per hectare using maize stover depends on both the amount of harvestable stover produced per hectare and the concentration and convertibility of the cell wall carbohydrates in the harvested stover. Variation exists for cell wall composition and digestibility traits at both the silage stage (approximately reproductive 3 (R3)) $[16,27,28,43]$ and physiological maturity (reproductive 6 (R6)) $[27,28]$. It has also been shown that breeding for forage yield and quality (cell wall composition and digestibility) has increased milk yields on both a per unit land and per unit mass basis [23]. Similarly, increasing the quality of maize stover for use as a biofeedstock through breeding and selection will have an impact in the efficiency of producing biofuels from cellulosic materials on both a per hectare and per ton basis.

Understanding how the relative values of genotypes vary across different developmental stages or plant parts would help determine if evaluations made earlier in plant development or on individual plant parts are predictive of whole-stover quality at physiological maturity, when maize stover for biofuel production is likely to be harvested. Variation in glucose production across cobs, leaves, and husks has been documented [29]. Furthermore, determining in which plant part and at which developmental stage genetic variation is the greatest would help improve the heritability of stover quality.

Our objectives were to (a) determine the cell wall composition of different maize plant parts, (b) determine the genotype-by-developmental stage and genotype-byplant part interactions for cell wall composition and digestibility, (c) determine if cell wall composition for any maize plant part at any developmental stage is 
correlated with whole-stover composition at physiological maturity, and (d) determine when genetic variation and repeatability for cell wall composition and digestibility is the greatest. To accomplish these objectives, we dissected 23 maize hybrids into component plant parts at four developmental stages and evaluated each plant part for cell wall composition.

\section{Methods}

Germplasm Twenty-three maize hybrids were evaluated in this experiment. Twenty hybrids were derived from a factorial mating design between five inbred lines derived from the Wisconsin Corn Silage and Biofeedstock Breeding Program [16, 30] and four commercial inbred testers. The five Wisconsin inbred lines were W601S, W602S, W603S, W604S, and W605S, and the four commercial testers were HC33, LH244, LH332 (Holden's Foundation Seeds), and TR7245 (Thurston Genetics). A brown-midrib3 (bm3) hybrid (Mycogen-F697), Leafyl (Lfyl) hybrid (Syngenta-N48V8), and a commercial grain hybrid (DeKalb_-DK5143) were also evaluated.

Field Evaluations Trials were grown during the summer of 2006 at the West Madison Agricultural Research Station (Madison, WI, USA) and the Arlington Agricultural Research Station (Arlington, WI, USA) using a randomized complete block design with two replications. The Madison location was planted on May 21, and the Arlington location was planted on June 5. The soil type at both locations is Plano silt loam (fine-silty, mixed mesic Typic Arguidoll). Summer temperatures were near the historical average. Precipitation levels were also average at both locations. Genotypes were evaluated in four-row plots $(6.1 \mathrm{~m}$ long, $0.76 \mathrm{~m}$ apart) planted to a density of 79,000 plants $\mathrm{ha}^{-1}$. Only the center two rows were harvested for dry weight measurements and sampling.

Plant Dissection and Sampling Plants were harvested at four developmental stages (vegetative 3 (V3), vegetative 12 (V12), R3 and R6). These developmental stages on average occurred at 24, 52, 120, and 153 days after planting, respectively. At the V3 stage, the leaf collar of the third leaf is visible. At the V12 stage, the leaf collar of the 12th leaf is visible. The R3 stage is the "milk stage", which occurs approximately 18 to 22 days after silking, indicated by a one third milk line. The R6 stage is physiological maturity, occurring approximately 55 to 65 days after silking [33] and being indicated by the formation of a black or brown abscission layer. At each developmental stage, five plants from each plot were removed from the field and dissected into gross tissue types. Tissue for each plant part from the five plants was bulked for the analysis. Tissues harvests and development stages studied were as follows:

V3 leaf blade

V12 leaf blade, leaf sheath, midrib, and stalk

R3 leaf blade, leaf sheath, midrib, stalk, cob, huskshank, and tassel

R6 leaf blade, leaf sheath, midrib, stalk, cob, huskshank, tassel, and whole-stover

Cell Wall Composition and Digestibility Analyses All biomass samples were dried for approximately seven days at $55^{\circ} \mathrm{C}$ and ground with a hammer mill to pass a $1-\mathrm{mm}$ screen. A NIRSystems 6500 near-infrared reflectance spectrometer was used to scan ground samples. NIR spectra were used to develop internal calibration equations for NDF, ADF, and IVTD. A single calibration equation was developed across all time points for each tissue type except leaf blade. Because leaf blade was collected at all four developmental stages studied (V3 to R6), resulting in more extreme variation within the leaf blade sample set, separate NIRS calibrations were developed for each development stage. Also, preliminary results showed that the error variance within genotypes is substantially greater when a single calibration across development stages was used compared to separate calibrations. This was not the case for plant parts harvested at three or fewer development stages. The SELECT procedure [35] with a standardized $H$ value of 1.0 was used to determine the calibration set for each sample type. The calibration set used for ADF and NDF was selected from NIR spectra of all of the replicates. The calibration set used for IVTD was selected from NIR spectra for one replication in each location. A global calibration created by the University of Wisconsin silage and biofeedstock breeding program was used for IVTD of whole plant samples at R6.

The ANKOM Filter Bag method (ANKOM Technology, Macedon, NY, USA) and ANKOM-200 Fiber Analyzer were used to sequentially analyzed NDF and ADF for the samples used in the NIRS calibration. Five hundred milligrams of ground stover was placed in ANKOM F57 filter bags and heat sealed. NDF was determined by weighing the residue after extraction with neutral detergent. Residue from the NDF wash was then subjected to acid detergent to determine ADF [40]. Detailed protocols can be found at the website of ANKOM Technology (http:// ANKOM.com/09 procedures/procedures.shtml).

Stover IVTD is the percent dry matter after a $48-\mathrm{h}$ incubation period in rumen fluid from a lactating Holstein cow and buffer solution [18]. ANKOM F57 filter bags were filled with $250 \mathrm{mg}$ ground stover and heat sealed. Samples were incubated with rumen fluid and buffer solution in the Daisy II Incubator (ANKOM Technology, Macedon, NY, 
USA) and subsequently washed with neutral detergent in an ANKOM-200 Fiber Analyzer.

The ISI NIRS 3 software version 3.11 was then used to determine modified partial least squares calibrations (Infrasoft International, Port Matilda, PA, USA). ADF, NDF, and IVTD calibrations were acceptable based on $R^{2}$ and standard error of cross validation values (Table 1 ). Due to the number of samples, the calibration set for IVTD is relatively small. However, correlations between predicted values and wet lab data were all significant at the 0.0001 level, with the exception of leaf blade IVTD at R3 and R6. A calibration could not be developed for leaf blade IVTD, for these samples wet lab data on one replication at each location was obtained and used in the analysis. ADF and NDF were predicted on all replicates for leaf blade at V3, V12, R3, and R6; leaf sheath, stalk, and midrib at V12, R3, and R6; husk-shank and cob at R3 and R6; and whole-stover at R6. IVTD was predicted on all replicates for leaf sheath, stalk, and cob at R3 and R6. These plant parts were chosen for IVTD because they constitute the largest portion of the plant at physiological maturity. ADF and NDF show changes in cell wall content over time and are highly correlated with NDFD. The following equation was used to calculate NDFD from IVTD and NDF: NDFD $=100\{[\mathrm{NDF}-(100-$ IVTD $)] / \mathrm{NDF}\}$. NDFD is the proportion of NDF fraction digested during the 48-h incubation in rumen fluid.

Statistical Analysis A mixed model analysis implemented in PROC MIXED was used to partition variation due to main effects of genotype (including hybrid, inbred, and tester), plant part, developmental stage, location, and replication nested within location as well as the interaction of genotype-by-location, genotype-by-plant part, and genotype-by-developmental stage and their interactions. Inbred as defined here refers to the average of four hybrids

Table 1 Near-infrared spectroscopy closed calibration statistics for predicting NDF, ADF, and IVTD constituents

\begin{tabular}{|c|c|c|c|c|c|c|}
\hline Compositional attributes & Plant part and developmental stage & Mathematical treatment & $N$ & Mean $(g / k g)^{a}$ & $R^{2}$ & SECV \\
\hline $\mathrm{NDF}$ & Stalk (V12, R3, R6) & $1-4-4-1$ & 76 & 678.1 & 0.99 & 10.0 \\
\hline $\mathrm{NDF}$ & Cob (R3, R6) & $1-4-4-1$ & 64 & 772.9 & 0.73 & 21.8 \\
\hline NDF & Leaf blade (V3) & $1-4-4-1$ & 36 & 583.7 & 0.96 & 6.9 \\
\hline $\mathrm{NDF}$ & Leaf blade (V12) & $1-4-4-1$ & 33 & 675.6 & 0.96 & 10.1 \\
\hline $\mathrm{NDF}$ & Leaf blade (R3) & $1-4-4-1$ & 33 & 631.0 & 0.98 & 10.7 \\
\hline NDF & Leaf blade (R6) & $1-4-4-1$ & 29 & 709.9 & 0.95 & 7.5 \\
\hline NDF & Leaf sheath (V12, R3, R6) & $1-2-2-1$ & 46 & 634.3 & 0.98 & 12.5 \\
\hline $\mathrm{NDF}$ & Husk-shank (R3, R6) & $2-3-3-1$ & 45 & 740.2 & 0.96 & 13.8 \\
\hline NDF & Midrib (V12, R3, R6) & $2-2-2-1$ & 47 & 685.4 & 0.99 & 15.9 \\
\hline NDF & Whole stover (R6) & $1-4-4-1$ & 37 & 700.8 & 0.83 & 16.1 \\
\hline $\mathrm{ADF}$ & Stalk (V12, R3, R6) & $1-4-4-1$ & 72 & 439.3 & 0.99 & 8.0 \\
\hline $\mathrm{ADF}$ & Cob (R3, R6) & $2-3-3-1$ & 62 & 444.9 & 0.95 & 14.4 \\
\hline $\mathrm{ADF}$ & Leaf blade (V3) & $1-4-4-1$ & 37 & 218.9 & 0.78 & 7.8 \\
\hline $\mathrm{ADF}$ & Leaf blade (V12) & $1-4-4-1$ & 32 & 296.4 & 0.99 & 3.9 \\
\hline $\mathrm{ADF}$ & Leaf blade (R3) & $1-4-4-1$ & 32 & 304.1 & 0.96 & 8.2 \\
\hline $\mathrm{ADF}$ & Leaf blade (R6) & $1-4-4-1$ & 27 & 344.7 & 0.96 & 7.6 \\
\hline $\mathrm{ADF}$ & Leaf sheath (V12, R3, R6) & $1-2-2-1$ & 47 & 369.4 & 0.97 & 9.5 \\
\hline $\mathrm{ADF}$ & Husk-shank (R3, R6) & $2-3-3-1$ & 47 & 397.1 & 0.94 & 11.4 \\
\hline $\mathrm{ADF}$ & Midrib (V12, R3, R6) & $1-2-2-1$ & 49 & 426.1 & 0.98 & 6.9 \\
\hline $\mathrm{ADF}$ & Whole stover (R6) & $1-4-4-1$ & 37 & 415.8 & 0.93 & 11.0 \\
\hline IVTD & Stalk (R3, R6) & $1-4-4-1$ & 21 & 563.2 & 0.98 & 19.7 \\
\hline IVTD & Cob (R3, R6) & $1-4-4-1$ & 33 & 574.7 & 0.83 & 20.4 \\
\hline IVTD & Leaf sheath (R3, R6) & $1-4-4-1$ & 19 & 671.7 & 0.98 & 17.6 \\
\hline IVTD & Whole stover (R6) & $1-4-4-1$ & 190 & 668.9 & 0.91 & 18.4 \\
\hline
\end{tabular}

Calibrations for NDF and ADF were developed based on 23 hybrids evaluated at two locations (Madison and Arlington, WI, USA) and two replications in each location in 2006. Calibrations for IVTD were developed based on one replication in each location

$N$ number of observations included in calibration equation, $S E C V$ standard error of cross validation, $N D F$ neutral detergent fiber, $A D F$ acid detergent fiber, IVTD in vitro true digestibility

${ }^{a}$ Mean sample concentration in calibration set 
created by crossing one of the five Wisconsin inbred lines to the four commercial testers, while tester refers to the average of five hybrids created by crossing one of the commercial testers to the five Wisconsin inbred lines. Inferences on the plant part effect and its interaction with genotype were made using models not including development stage as a source of variation. Inferences on the developmental stage effect and its interaction with genotype were made using models not including plant part as a source of variation. Thus, models involving development stage were separated by individual plant parts, and models involving plant part were separated by individual development stages. A linear model was used which included hybrid and plant part main effects and their interaction as fixed effects and location and replication nested within location as random effects. The genotype-by-location interaction term was not a significant source of variation; therefore, its mean squares were pooled with the residual variation. A similar model was used to test developmental stage and its interaction with hybrid, with the exception that developmental stage was modeled as a repeated factor. To maximize model fit, the covariance structure of the residual covariance matrix was modeled as simple, unstructured, compound symmetric, and heterogeneous compound symmetric, and the best model for each plant part was chosen on the basis of Bayesian information criterion (SAS [34]). Pearson product-moment correlations involving the 23 hybrid means were used to test the influence of individual plant part quality on whole-stover quality both at R6 and earlier stages.

Repeatability on a hybrid-mean basis was calculated for each plant part-by-developmental stage combination by partitioning the sources of variation with a random model that included hybrid, location, hybrid-by-location interaction, and replication nested within location. Repeatability was calculated as: $R=\sigma_{\mathrm{H}}^{2} /\left(\sigma_{\mathrm{H}}^{2}+\sigma_{\mathrm{HL}}^{2} / 2+\sigma_{\mathrm{r}}^{2} / 4\right)$ where $\sigma_{\mathrm{H}}^{2}$ is the variance between hybrids, $\sigma_{\mathrm{HL}}^{2}$ is the variance due to hybrid-by-location interaction, and $\sigma_{\mathrm{r}}^{2}$ is the residual variance.

\section{Results}

Cell Wall Composition of Maize Stover Parts Across Developmental Stages Contributions of each plant part to total stover dry matter weight at physiological maturity was determined (Table 2). Stalk contributes the most biomass at physiological maturity, constituting $46.2 \%$ of the dry matter weight. The next largest contributor to stover dry matter weight is total leaf $(30.2 \%)$, which consists of leaf blade, leaf sheath, and midrib (Table 2).

Stalk was the least digestible plant part analyzed based on convertibility of the cell wall fraction measured in this
Table 2 Percent of the total dry matter weight and fiber digestibility of different plant parts at R6

\begin{tabular}{lclll}
\hline Plant part & Percent dry matter & ADF $(\mathrm{g} / \mathrm{kg})$ & $\begin{array}{l}\mathrm{NDF} \\
(\mathrm{g} / \mathrm{kg})\end{array}$ & $\begin{array}{l}\mathrm{NDFD}^{\mathrm{a}} \\
(\mathrm{g} / \mathrm{kg})\end{array}$ \\
\hline Stalk & 46.2 & 470.0 & 709.0 & 375.0 \\
Cob & 13.4 & 445.0 & 779.0 & 443.0 \\
Leaf blade & 12.3 & 346.0 & 716.0 & 579.0 \\
Leaf sheath & 11.7 & 394.0 & 715.0 & 515.0 \\
Husk-shank & 9.6 & 406.0 & 762.0 & $\mathrm{NR}$ \\
Midrib & 6.2 & 449.0 & 699.0 & $\mathrm{NR}$ \\
Tassel & 0.6 & $\mathrm{NR}$ & $\mathrm{NR}$ & $\mathrm{NR}$ \\
\hline
\end{tabular}

Values are averages of 23 hybrids evaluated at two locations (Madison and Arlington, WI, USA) and two replications in each location in 2006

$N R$ not recorded

${ }^{\mathrm{a}} \mathrm{NDFD}=100\{[\mathrm{NDF}-(100-\mathrm{IVTD})] / \mathrm{NDF}\}$

study as NDFD. Stalk digestibility was $375.0 \mathrm{~g} / \mathrm{kg}$ whereas leaf blade and leaf sheath were the most digestible plant parts at 579.0 and $515.0 \mathrm{~g} / \mathrm{kg}$, respectively (Table 2).

ADF for each plant part was analyzed across developmental stages to evaluate the effect of plant part on stover compositional changes over time. The ADF fraction was determined for leaf blade, leaf sheath, stalk, and midrib at the V12, R3, and R6 stages and leaf blade only at the V3 stage. ADF was determined for husk-shank and cob at R3 and R6 only, as these were the only developmental stages at which these tissue types were present. For all tissue types, the ADF increased throughout development, consistent with the expectation that secondary cell wall formation and lignifications are the greatest in adult tissues (Fig. 1).

Genotype-by-Developmental Stage and Genotype-by-Plant Part Interactions Differences in ADF and NDFD were observed $(p<0.05)$ between hybrids and inbreds for most plant parts. Exceptions include lack of differences between hybrids for midrib ADF and leaf sheath NDFD and between inbreds for cob ADF and midrib ADF. The only differences detected between the testers were for cob and husk-shank ADF and cob NDFD (Table 3).

Genotype-by-developmental stage and genotype-byplant part interactions were studied to determine if the relative performance of genotypes for compositional attributes depends upon which development stage and plant part is harvested for analysis. Hybrid-by-developmental stage interactions were observed for midrib ADF and cob NDFD. Inbred-by-developmental stage interactions were observed for cob and midrib ADF. Tester-by-developmental stage interaction was observed for leaf blade ADF and cob NDFD (Table 3). This suggests that the relative performance of genotypes for stover compositional characteristics depends 


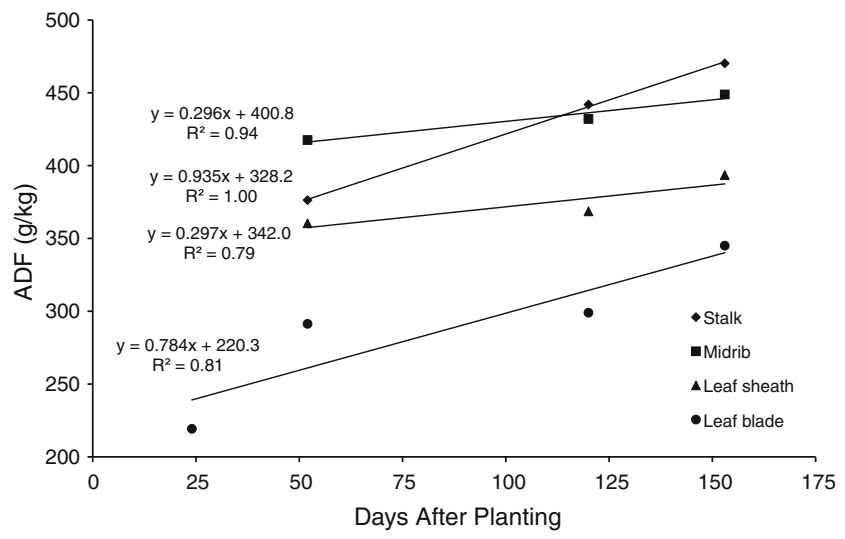

Fig. 1 Changes in acid detergent fiber $(A D F)$ throughout development for leaf blade, leaf sheath, midrib, and stalk fractions. ADF is the average of 23 hybrids evaluated at two locations (Madison and Arlington, WI, USA) and two replications in each location in 2006

on the developmental stage at which tissue is harvested. The smaller number of genotype-by-developmental stage interactions observed for NDFD relative to ADF could be due to the fact that NDFD was measured for fewer development stages (R3 and R6) compared to ADF (V3, V12, R3, and R6).

Hybrid- and inbred-by-plant part interactions were observed for NDFD, and inbred-by-plant part interactions were observed for both ADF and NDFD (Table 4). This suggests that the relative performance of genotypes for stover compositional attributes can depend on the plant part analyzed. Changes in rank were also observed for genotype-by-plant part interactions.

Correlation Between Plant Parts and Whole-Stover Composition at R6 Pearson correlations between plant parts at each developmental stage and whole-stover composition at physiological maturity were determined for ADF, NDF, and NDFD (Table 5). Although several positive correlations were found, their low magnitude suggests that composition of individual plant parts both at R6 and earlier stages is not a good enough predictor of whole-stover composition to warrant selection at earlier stages or on individual plant parts. This could be due to differences across genotypes in complex interactions between genetic factors and development stages and plant parts or to differences in the proportions of plant parts making up the whole-stover sample. There were few significant correlations between individual plant parts across developmental stages. These correlations included stalk, leaf blade, leaf sheath, and husk-shank between R3 and R6 for ADF (data not shown). No significant correlations were found between individual plant parts before and after flowering.

Genetic Variation and Repeatability for Stover Composition and Digestibility The repeatability on a hybrid-mean basis for each plant part-by-development stage combination was estimated to determine at what development stage ratios of genetic variation to nongenetic variation

Table 3 ANOVA for hybrid, inbred, and tester effects across plant parts and their interactions with developmental stages

\begin{tabular}{|c|c|c|c|c|c|c|c|c|c|c|}
\hline \multirow[b]{2}{*}{ Source of variation } & \multicolumn{6}{|l|}{$\mathrm{ADF}$} & \multicolumn{4}{|l|}{ NDFD } \\
\hline & Stalk $^{\mathrm{c}}$ & $\mathrm{Cob}^{\mathrm{d}}$ & $\begin{array}{l}\text { Leaf } \\
\text { Blade }^{e}\end{array}$ & $\begin{array}{l}\text { Leaf } \\
\text { Sheath }^{\mathrm{c}}\end{array}$ & $\begin{array}{l}\text { Husk- } \\
\text { Shank }^{d}\end{array}$ & Midrib $^{c}$ & Stalk $^{\mathrm{d}}$ & $\mathrm{Cob}^{\mathrm{d}}$ & $\begin{array}{l}\text { Leaf } \\
\text { Blade }^{\mathrm{d}}\end{array}$ & $\begin{array}{l}\text { Leaf } \\
\text { Sheath }^{\mathrm{d}}\end{array}$ \\
\hline Hybrid & 0.038 & 0.001 & 0.016 & 0.002 & $<0.001$ & NS & $<0.001$ & $<0.001$ & 0.032 & NS \\
\hline Hybrid $\times$ developmental stage & NS & NS & NS & NS & NS & 0.040 & NS & 0.032 & NS & NS \\
\hline Inbred $^{\mathrm{a}}$ & 0.004 & NS & $<0.001$ & $<0.001$ & $<0.001$ & NS & $<0.001$ & $<0.001$ & $<0.001$ & 0.006 \\
\hline Inbred $\times$ developmental stage & NS & 0.029 & NS & NS & NS & 0.001 & NS & NS & NS & NS \\
\hline Tester $^{\mathrm{b}}$ & NS & $<0.001$ & NS & NS & 0.004 & NS & NS & $<0.001$ & NS & NS \\
\hline Tester $\times$ developmental stage & NS & NS & 0.002 & NS & NS & NS & NS & 0.041 & NS & NS \\
\hline
\end{tabular}

Developmental stage was treated as a repeated measurement. Hybrids were evaluated in two replications at two locations in Wisconsin (West Madison and Arlington, WI, USA) in 2006

NS not significant at $p=0.05$

${ }^{\mathrm{a}}$ Inbred = average of four hybrids created by crossing one of the inbred lines from the Wisconsin Corn Silage and Biofeedstock Breeding Program (W601S, W602S, W603S, W604S, or W605S) to four commercial testers (HC33, LH244, LH332, and TR7245)

${ }^{\mathrm{b}}$ Tester $=$ average of five hybrids created by crossing one of the commercial testers (HC33, LH244, LH332, or TR7245) to five inbred lines from the Wisconsin Corn Silage and Biofeedstock Breeding Program (W601S, W602S, W603S, W604S, and W605S)

${ }^{\mathrm{c}}$ Plant part measured at V12, R3, and R6

${ }^{\mathrm{d}}$ Plant part measured at R3 and R6

${ }^{\mathrm{e}}$ Plant part measured at V3, V12, R3, and R6 
Table 4 ANOVA for hybrid, inbred, and tester effects across developmental stages and their interactions with plant parts

\begin{tabular}{|c|c|c|c|c|c|}
\hline \multirow[b]{2}{*}{ Source of variation } & \multicolumn{3}{|c|}{ ADF $(g / k g)$} & \multicolumn{2}{|c|}{ NDFD (g/kg) } \\
\hline & $\mathrm{V} 12^{\mathrm{c}}$ & $\mathrm{R} 3^{\mathrm{d}}$ & $\mathrm{R} 6^{\mathrm{d}}$ & $\mathrm{R} 3^{\mathrm{e}}$ & $\mathrm{R} 6^{\mathrm{e}}$ \\
\hline Hybrid & NS & $<0.001$ & $<0.001$ & 0.004 & $<0.001$ \\
\hline Hybrid $\times$ plant part & NS & NS & NS & NS & $<0.001$ \\
\hline Inbred $^{\mathrm{a}}$ & 0.014 & $<0.001$ & 0.006 & $<0.001$ & $<0.001$ \\
\hline Inbred $\times$ plant part & $<0.001$ & 0.009 & NS & $<0.001$ & $<0.001$ \\
\hline Tester $^{\mathrm{b}}$ & NS & NS & 0.001 & NS & NS \\
\hline Tester $\times$ plant part & NS & NS & NS & NS & NS \\
\hline
\end{tabular}

Hybrids were evaluated in two replications at two locations in Wisconsin (Madison and Arlington, WI, USA) in 2006

NS not significant at $p=0.05$

${ }^{a}$ Inbred = average of four hybrids created by crossing one of the inbred lines from the Wisconsin Corn Silage and Biofeedstock Breeding Program (W601S, W602S, W603S, W604S, or W605S) to four commercial testers (HC33, LH244, LH332, and TR7245)

${ }^{\mathrm{b}}$ Tester $=$ average of five hybrids created by crossing one of the commercial testers (HC33, LH244, LH332, or TR7245) to five inbred lines from the Wisconsin Corn Silage and Biofeedstock Breeding Program (W601S, W602S, W603S, W604S, and W605S)

${ }^{\mathrm{c}}$ Stalk, leaf blade, leaf sheath, and midrib measured

${ }^{\mathrm{d}}$ Stalk, cob, leaf blade, leaf sheath, husk-shank, and midrib measured

${ }^{\mathrm{e}}$ Stalk, cob, leaf blade, and leaf sheath measured

was the greatest. Repeatability sets an upper limit to heritability by quantifying the importance of variation among genotypes relative to variation within genotypes caused by multiple measurements [15]. The repeatability of the ADF and NDFD fractions was analyzed for each plant part throughout development. In general, repeatability increased from earlier stages to later stages of development for both ADF and NDFD, with the exception of the stalk and husk-shank fractions for ADF and the stalk fraction for NDFD (Table 6). This finding suggests that the genetic differences become more apparent later in the plant life cycle.

\section{Discussion}

It is currently proposed that maize stover can be used as a source of biomass for lignocellulosic biofuel production.

Table 5 Pearson correlations between whole-stover sample at R6 and stalk, leaf blade, leaf sheath, and midrib at three developmental stages for ADF, NDF, and NDFD

\begin{tabular}{|c|c|c|c|c|c|c|c|}
\hline \multirow[b]{2}{*}{ Developmental stage } & \multirow[b]{2}{*}{ Plant part } & \multicolumn{2}{|l|}{$\operatorname{ADF}(g / k g)$} & \multicolumn{2}{|l|}{ NDF $(g / k g)$} & \multicolumn{2}{|l|}{ NDFD (g/kg) } \\
\hline & & Whole stover & $p$ value & Whole stover & $p$ value & Whole stover & $p$ value \\
\hline V12 & Stalk & NS & - & 0.419 & 0.047 & NR & - \\
\hline V12 & Leaf blade & NS & - & NS & - & NR & - \\
\hline V12 & Leaf sheath & NS & - & 0.427 & 0.042 & NR & - \\
\hline V12 & Midrib & NS & - & NS & - & NR & - \\
\hline R3 & Stalk & 0.472 & 0.023 & 0.481 & 0.020 & 0.591 & 0.007 \\
\hline $\mathrm{R} 3$ & Leaf blade & NS & - & NS & - & NS & - \\
\hline $\mathrm{R} 3$ & Leaf sheath & NS & - & NS & - & NS & - \\
\hline R3 & Midrib & NS & - & NS & - & NR & - \\
\hline R6 & Stalk & 0.544 & 0.007 & 0.541 & 0.008 & 0.548 & 0.013 \\
\hline R6 & Leaf blade & NS & - & NS & - & 0.414 & 0.049 \\
\hline R6 & Leaf sheath & NS & - & NS & - & NS & - \\
\hline R6 & Midrib & 0.495 & 0.016 & 0.464 & 0.026 & NR & - \\
\hline
\end{tabular}

Averages were calculated across two locations (Madison and Arlington, WI, USA) and two replications per location in 2006

$A D F$ acid detergent fiber, $N D F$ neutral detergent fiber, $N D F D$ neutral detergent fiber digestibility, $N S$ not significant at $p=0.05, N R$ not recorded 
Table 6 Repeatability estimates for plant parts across developmental stages for ADF and NDFD

\begin{tabular}{llll}
\hline & & \multicolumn{2}{l}{ Repeatability } \\
\cline { 3 - 4 } Plant part & Developmental stage & ADF $(\mathrm{g} / \mathrm{kg})$ & NDFD $(\mathrm{g} / \mathrm{kg})$ \\
\hline Leaf blade & V3 & 0.08 & - \\
Stalk & V12 & 0.29 & - \\
Leaf blade & V12 & 0.33 & - \\
Leaf sheath & V12 & 0.19 & - \\
Midrib & V12 & 0.30 & - \\
Stalk & R3 & 0.54 & 0.69 \\
Cob & R3 & 0.41 & 0.69 \\
Leaf blade & R3 & 0.58 & 0.33 \\
Leaf sheath & R3 & 0.58 & 0.41 \\
Husk-shank & R3 & 0.71 & - \\
Midrib & R3 & 0.44 & - \\
Stalk & R6 & 0.17 & 0.62 \\
Cob & R6 & 0.53 & 0.78 \\
Leaf blade & R6 & 0.77 & 0.67 \\
Leaf sheath & R6 & 0.58 & 0.52 \\
Husk-shank & R6 & 0.47 & - \\
Midrib & R6 & 0.53 & - \\
Whole stover & R6 & 0.48 & 0.76 \\
& & &
\end{tabular}

Averages were calculated across two locations (Madison and Arlington, WI, USA) and two replications per location in 2006

$A D F$ acid detergent fiber, $N D F D$ neutral detergent fiber digestibility

Stover therefore is presented as a coproduct of the grain production, which will continue to be consumed mostly as a source of food and feed. Delaying harvest until physiological maturity (R6) allows the grain to mature as well as the moisture content of the stover to be reduced, which will make transportation of the biomass to the biorefineries more efficient.

It has been suggested that a harvesting strategy, which selectively removes the most digestible plant parts, would maximize the efficiency of converting a biofeedstock into ethanol $[13,36]$. In addition to increasing the conversion efficiency, this would also allow for more residues to remain on the field which will help maintain soil fertility and productivity.

The cell wall composition of different maize plant parts throughout development was determined in this study. Results from this experiment have provided detailed evidence that the leaf (leaf blade, leaf sheath, and midrib) is the most desirable to collect within a selectable harvesting strategy, due to the high digestibility of this portion of the plant. The leaf, however, comprises less than one third of the total dry matter. The stalk, on the other hand, contributes the largest proportion to the total stover biomass; however, this tissue type would be a less than ideal source of biofeedstock for conversion to ethanol due to its inferior digestibility. Thus, it is critical to first determine the economics of the conversion of biofeedstock to lignocellulosic ethanol before strict recommendations can be made about selective harvesting strategies.

Recent research efforts within the area of lignocellulosic ethanol production have focused heavily on identifying genes involved in secondary cell wall synthesis in an attempt to change the overall composition of the plant [17, $24,31,41]$. This study has shown that there is a great range of variability for digestibility across plant parts. Perhaps selection efforts to alter the proportion of the plant parts could prove to be another productive method to increase the yield of ethanol per hectare. For example, mutants such as leafyl that increase the number of leaves on the plant above the ear are currently used in maize silage hybrids as a means to increase yield $[10,14]$ and might also be useful for the production of biofeedstock.

Correlations for different cell wall composition and digestibility traits between hybrids at R3 (when silage is normally harvested) and R6 have been observed [26]. Another goal of this study was to determine if there is a tissue type at an earlier developmental stage that would be predictive of whole-stover cell wall composition and digestibility at physiological maturity. The ability to select for genotypes that will be higher quality at maturity based on a trait measured before flowering would increase the efficiency and rate of gain that can be made from selection on a per-year basis. Successful indirect selection has been demonstrated for various traits and crops [7, 44]. In these studies, greater selection responses were observed when the heritability of the trait to be evaluated as well as the correlation between the indirect and direct targets of selection were relatively high.

This study indicates that measurements of biomass quality early in the season are not predictive of biomass quality late in the season. Therefore, stover quality must be determined at harvest time to accurately identify high quality genotypes. The lack of correlations with early developmental stages, primarily before grain filling, could be explained by the presence of different efficiencies of remobilizing sugars to the ear in different genotypes [2,9], as well as the ability of different tissue types within the same genotype to have different efficiencies of remobilizing sugars to the ear and altered physiology throughout development [4, 20, 21, 28].

In addition to a lack of correlation between early plant part digestibility and whole plant digestibility at R6, there is also less variation for this trait at these early developmental stages. Gain from selection is maximized when genetic variation and repeatability are maximized. This study has shown that, in general, this is achieved at later stages of development. 
Selection for cell wall compositional traits can be effective [23, 43]. It is important to remember, however, that the results of selection directly reflect what the direct object of selection is. If the heritability of the primary trait of interest is low or the trait is difficult to measure, selection on a secondary and related trait can be effective in allowing more significant or faster progress from the process of selection. This study has shown that there are significant hybrid-by-developmental stage and hybrid-by-plant part interactions. Also, there are few correlations for some compositional traits and no correlation for digestibility between plant parts at early developmental stages and whole-stover at physiological maturity. In addition, repeatability of different plant parts generally increases throughout development. Thus, all evidence from this study indicates that phenotyping early in development will not lead to large gains from selection for cell wall compositional traits in maize. Information gained from this study does, however, provide additional evidence that leaf would be the most desirable tissue to remove from the field if the objective is to maximize conversion efficiency of maize biofeedstock into ethanol.

Acknowledgments The authors would like to acknowledge Dustin Eilert, Pat Flannery, and Robert Vogelzang for technical assistance. This work was supported by USDA Hatch Funds project 02208863 and the US Department of Energy through the Great Lakes Bioenergy Research Center Grant DE-FC02-07ER64494.

\section{References}

1. Armstrong K, Albrecht K, Lauer J, Riday H (2008) Intercropping corn with lablab bean, velvet bean, and scarlet runner bean for forage. Crop Sci 48:371-379

2. Bertoia L, Lopez C, Burak R (2006) Biplot analysis of forage combining ability in maize landraces. Crop Sci 46:1346-1353

3. Casler M, Diaby M (2008) Positive genetic correlation between forage yield and fiber of smooth bromegrass. Crop Sci 48:21532158

4. Chen L, Auh C, Chen F, Cheng X, Aljoe H, Dixon R et al (2002) Lignin deposition and associated changes in anatomy, enzyme activity, gene expression, and ruminal degradability in stems of tall fescue at different developmental stages. J Agric Food Chem 50:5558-5565

5. Claessens A, Michaud R, Belanger G, Mather D (2005) Leaf and stem characteristics of timothy plants divergently selected for the ratio of lignin to cellulose. Crop Sci 45:2425-2429

6. Coblentz W, Hoffman P (2009) Effects of spontaneous heating on fiber composition, fiber digestibility, and in situ disappearance kinetics of neutral detergent fiber for alfalfa-orchardgrass hays. J Dairy Sci 92:2875-2895

7. Conaghan P, Casler M, O'Kiely P, Dowley L (2008) Efficiency of indirect selection for dry matter yield based on fresh matter yield in perennial ryegrass sward plots. Crop Sci 48:127-133

8. Contreras-Govea F, Albrecht K (2006) Forage production and nutritive value of oat in autumn and early summer. Crop Sci $46: 2382-2386$
9. Coors J, Albrecht K, Bures E (1997) Ear-fill effects on yield and quality of silage corn. Crop Sci 37:243-247

10. Cox W, Cherney D (2001) Influence of brown midrib, leafy, and transgenic hybrids on corn forage production. Argron J 93:790-796

11. Dien B, Jung H, Vogel K, Casler M, Lamb J, Iten L et al (2006) Chemical composition and response to dilute-acid pretreatment and enzymatic saccharification of alfalfa, reed canarygrass, and switchgrass. Biomass Bioenergy 30:880-891

12. Dowe N, McMillan J (2001) SSF experimental protocols: lignocellulosic biomass hydrolysis and fermentation. National Renewable Energy Laboratory (NREL) Analytical Procedures. http://www.nrel.gov/biomass/pdfs/42630.pdf

13. Duguid K, Montross M, Radtke C, Crofcheck C, Shearer S, Hoskinson R (2007) Screening for sugar and ethanol processing characteristics from anatomical fractions of wheat stover. Biomass Bioenergy 30:585-592

14. Dwyer L, Stewart D, Glenn F (1998) Silage yields of leafy and normal hybrids. Proceedings of the 53rd Annual Corn \& Sorghum Research Conference, p 193

15. Falconer D, Mackay T (1996) Introduction to quantitative genetics, 4th edn. Pearson Prentice Hall, Edinburgh

16. Frey T, Coors J, Shaver R, Lauer J, Eilert D, Flannery P (2004) Selection for silage quality in the Wisconsin quality synthetic and related maize populations. Crop Sci 44:1200-1208

17. Gille S, Hänsel U, Ziemann M, Pauly M (2009) Identification of plant cell wall mutants by means of a forward chemical genetic approach using hydrolases. Proc Natl Acad Sci 106:14699-14704

18. Goering H, Van Soest P (1970) Forage fiber analysis: apparatus reagents, procedures and some applications. Agricultural Research Service, USDA, agricultural handbook no. 379. Agricultural Research Service, USDA, Washington, DC

19. Isci A, Murphy PT, Anex RP, Moore KJ (2008) A rapid simultaneous saccharification and fermentation (SSF) technique to determine ethanol yields. Bioenerg Res 1:163-169

20. Jung H, Casler M (2006) Maize Stem tissues: cell wall concentration and composition during development. Crop Sci 46:1793-1800

21. Jung H, Casler M (2006) Maize stem tissues: impact of development on cell wall degradability. Crop Sci 46:1801-1809

22. Lamb J, Sheaffer C, Rhodes L, Sulc R, Undersander D, Brummer E (2006) Five decades of alfalfa cultivar improvement: impact on forage yield, persistence, and nutritive value. Crop Sci 46:902909

23. Lauer J, Coors J, Flannery P (2001) Forage yield and quality of corn cultivars developed in different eras. Crop Sci 41:14491455

24. Li M, Xiong G, Li R, Cui J, Tang D, Zhang B et al (2009) Rice cellulose synthase-like D4 is essential for normal cell-wall biosynthesis and plant growth. Plant J 15:676-680

25. Lin Y, Tanaka S (2006) Ethanol fermentation from biomass resources: current state and prospects. Appl Microbiol Biotechnol 69:627-642

26. Lorenz A, Anex R, Isci A, Coors J, de Leon N, Weimer P (2009) Forage quality and composition measurements as predictors of ethanol yield from maize (Zea mays L.) stover. Biotechnol Biofuels 2:5

27. Lorenz A, Coors J, de Leon N, Wolfrum E, Hames B, Sluiter A et al (2009) Characterization, genetic variation, and combining ability of maize traits relevant to the production of cellulosic ethanol. Crop Sci 49:85-98

28. Lundvall J, Buxton D, Hallauer A, George J (1994) Forage quality variation among maize inbreds: in vitro digestibility and cell-wall components. Crop Sci 34:1672-1678

29. Montross M, Crofcheck C (2004) Effect of stover fraction and storage method on glucose production during enzymatic hydrolysis. Bioresour Technol 92:269-274 
30. Nass LL, Coors JG (2003) Potential of exotic x adapted maize germplasm for silage. Maydica 48:197-206

31. Pauly M, Keegstra K (2008) Cell-wall carbohydrates and their modifications as a resource for biofuels. Plant J 54:559-568

32. Perlack R, Wright L, Turhollow A, Graham R, Stokes B, Erbach D (2005) Biomass as feedstock for a bioenergy and bioproduct industry: The technical feasibility of a billion-ton annual supply. US DOE and USDA, Washington, DC

33. Ritchie S, Hanway J, Benson G (2008) How a corn plant develops. Iowa State University of Science and Technology Cooperative Extension Service Ames, Iowa special report no. 48

34. SAS Institute (2003) The SAS system for windows version 9.1. SAS Institute, Cary

35. Shenk J, Westerhaus M (1991) Population definition, sample selection, and calibration procedures for near infrared reflectance spectroscopy. Crop Sci 31:469-474

36. Shinners K, Binversie B (2007) Fractional yield and moisture of corn stover biomass produced in the Northern US Corn Belt. Biomass Bioenergy 31:576-584

37. Stern M, Bach A, Calsamiglia S (1997) Alternative techniques for measuring nutrient digestion in ruminants. J Anim Sci 75:2256-2276
38. Struik P (1983) Physiology of forage maize (Zea mays L.) in relation to its production and quality. Dissertation, Department of Field Crops and Grassland Science, Agricultural University, Wageningen, Netherlands

39. Vanholme R, Morreel K, Ralph J, Boerjan W (2008) Lignin engineering. Curr Opin Plant Biol 11:278-285

40. Van Soest P (1994) Nutritional ecology of the ruminant. Cornell University Press, Ithaca

41. Vermerris W, Saballos A, Ejeta G, Mosier N, Ladisch M, Carpita $\mathrm{N}$ (2007) Molecular breeding to enhance ethanol production from corn and sorghum stover. Crop Sci 47:S142-S153

42. Weimer P, Dien B, Springer T, Vogel K (2005) In vitro gas production as a surrogate measure of the fermentability of cellulosic biomass to ethanol. Appl Microbiol Biotechnol 67:52-58

43. Wolf D, Coors J, Albrecht K, Undersander D, Carter P (1993) Forage quality of maize genotypes selected for extreme fiber concentrations. Crop Sci 33:1353-1359

44. Zhao D, Atlin G, Bastiaans L, Spiertz J (2006) Cultivar weedcompetitiveness in aerobic rice: heritability, correlated traits, and the potential for indirect selection in weed-free environments. Crop Sci 46:372-380 